\title{
Seismic Performance Assessment of Hollow Reinforced Concrete and Prestressed Concrete Bridge Columns
}

\author{
Tae-Hoon Kim ${ }^{1), *}$, Dai-Jeong Seong ${ }^{2)}$, and Hyun Mock Shin ${ }^{2)}$
}

(Received May 24, 2012, Revised August 1, 2012, Accepted August 2, 2012, Published online September 18, 2012)

\begin{abstract}
The aim of this study is to assess the seismic performance of hollow reinforced concrete and prestressed concrete bridge columns, and to provide data for developing improved seismic design criteria. By using a sophisticated nonlinear finite element analysis program, the accuracy and objectivity of the assessment process can be enhanced. A computer program, RCAHEST (Reinforced Concrete Analysis in Higher Evaluation System Technology), is used to analyze reinforced concrete and prestressed concrete structures. Tensile, compressive and shear models of cracked concrete and models of reinforcing and prestressing steel were used to account for the material nonlinearity of reinforced concrete and prestressed concrete. The smeared crack approach was incorporated. The proposed numerical method for the seismic performance assessment of hollow reinforced concrete and prestressed concrete bridge columns is verified by comparing it with the reliable experimental results. Additionally, the studies and discussions presented in this investigation provide an insight into the key behavioral aspects of hollow reinforced concrete and prestressed concrete bridge columns.
\end{abstract}

Keywords: seismic performance, hollow reinforced concrete and prestressed concrete bridge columns, nonlinear finite analysis program, material nonlinearity, smeared crack.

\section{Introduction}

Hollow bridge columns have become increasingly popular in bridge construction during the last few decades. Hollow sections are often used for tall bridge columns to reduce their mass, reduce seismic inertia forces, and reduce foundation forces. However, the seismic performance of hollow bridge columns is still not fully understood although a few works have been conducted (Hoshikuma and Priestley 2000; Maekawa et al. 2001; Ranzo and Priestley 2001; Yeh et al. 2002; Mo et al. 2003).

In locations where the cost of concrete is relatively high, or in situations where the weight of concrete members must be kept to a minimum, it may be economical to use hollow reinforced concrete vertical members. The hollow core also ensures greater quality control during construction by reducing the heat of hydration on the interior of the section and hence minimizing shrinkage cracks caused by temperature differences inside the curing column.

\footnotetext{
${ }^{1)}$ Construction Product Technology Research Institute, Samsung Construction \& Trading Corporation, Seoul 135-935, Korea.

*Corresponding Author;

E-mail: th1970.kim@samsung.com

${ }^{2)}$ Department of Civil and Environmental Engineering, Sungkyunkwan University, Gyeonggi-do 440-746, Korea.

Copyright $($ The Author(s) 2012. This article is published with open access at Springerlink.com
}

Such columns, when properly detailed, were shown to perform in a ductile manner during cyclic lateral loading in the inelastic range, since the core of the tube walls was well confined by the reinforcement (Zahn et al. 1990). It has been well established that well-confined concrete members can sustain large concrete compressive strains without significant loss of compressive strength (Hines et al. 2002).

The main goal of this study is to provide basic knowledge on the seismic performance of hollow reinforced concrete and prestressed concrete bridge columns. In this paper, hollow bridge columns were tested under a constant axial load and a pseudostatic, cyclically reversed horizontal load. The effects of ductility and dissipated energy were also investigated.

An evaluation method for the seismic performance of hollow reinforced concrete and prestressed concrete bridge columns is proposed. The proposed method uses a nonlinear finite element analysis program RCAHEST (Reinforced Concrete Analysis in Higher Evaluation System Technology) developed by the authors (Kim et al. 2003; Kim et al. 2007; Kim et al. 2008; Kim et al. 2009; Kim et al. 2010). To assess the ability of the RCAHEST program to predict the seismic performance of hollow reinforced concrete and prestressed concrete bridge columns, computed results using the program were compared with the test results.

\section{Computational Platform for Seismic Performance Assessment}

A two-dimensional finite element model for the seismic performance assessment of hollow reinforced concrete and 
prestressed concrete bridge columns was developed in this study. A three-dimensional finite element analysis is tedious and computationally expensive, and requires a high number of elements to achieve a good accuracy.

The model was created and analyzed using general-purpose finite element software, RCAHEST (Kim et al. 2003; Kim et al. 2007; Kim et al. 2008; Kim et al. 2009; Kim et al. 2010). RCAHEST is a nonlinear finite element analysis program used for analyzing reinforced concrete structures (see Fig. 1).

The structural element library of RCAHEST, is built around the finite element analysis program shell named FEAP, developed by Taylor (2000). The elements developed for the nonlinear finite element analyses of reinforced concrete bridge columns are a reinforced concrete plane stress element and an interface element (Kim et al. 2003; Kim et al. 2007; Kim et al. 2008; Kim et al., 2009). Accompanying the present study, the authors attempted to implement a bonded tendon element and a modified joint element for the segmental joints with a shear resistance connecting structure (Kim et al. 2010).

The nonlinear material model for the reinforced and prestressed concrete comprises models for concrete and models for the reinforcing bars and tendons. Models for concrete may be divided into models for uncracked concrete and for cracked concrete. For cracked concrete, three models describe the behavior of concrete in the direction normal to the crack plane, in the direction of the crack plane, and in the shear direction at the crack plane, respectively (see Fig. 2). The basic and widely-known model adopted for crack representation is based on the non-orthogonal fixed-crack method of the smeared crack concept. For the tension stiffening model for unloading and reloading, the model proposed by Shima et al. (1987) is basically used. For the compression stiffness model and shear transfer model for unloading and reloading, the model modified by the authors is used, respectively. The post-yield constitutive law for the reinforcing bar in concrete considers the bond characteristics, and the model is a bilinear model, as shown in Fig. 3 (Kim et al. 2003). Kato's model (1979) for the bare bar under the reversed cyclic loading and the assumption of a

\begin{tabular}{|c|c|c|c|}
\hline $\begin{array}{c}\text { 2D or 3D } \\
\text { Spring element }\end{array}$ & $\begin{array}{c}\text { 4 nodes PSC } \\
\text { shell element }\end{array}$ & $\begin{array}{c}\text { 2D or 3D } \\
\text { Flexibility- } \\
\text { based fiber } \\
\text { beam-column } \\
\text { element }\end{array}$ & $\begin{array}{c}\text { 4 nodes Elastic } \\
\text { shell element }\end{array}$ \\
\hline Joint element & \multicolumn{2}{|c|}{$\begin{array}{c}\text { Element library } \\
\text { in RCAHEST }\end{array}$} & $\begin{array}{c}\text { 4 nodes RC } \\
\text { shell element }\end{array}$ \\
\hline $\begin{array}{c}\text { Bonded or } \\
\text { Unbonded } \\
\text { bar estressing }\end{array}$ & $\begin{array}{c}\text { Interface } \\
\text { element }\end{array}$ & $\begin{array}{c}\text { RC } \\
\text { plane stress } \\
\text { element }\end{array}$ & $\begin{array}{c}\text { Lap spliced } \\
\text { bar element }\end{array}$ \\
\hline
\end{tabular}

Fig. 1 RCAHEST nonlinear finite element analysis program. cosinusoidal stress distribution were used to derive the mechanical behavior of reinforcing bars in concrete under reversed cyclic loading. For prestressing tendons that do not have a definite yield point, a multilinear approximation may be required. In this study, the trilinear model has been used for the stress-strain relationship of the prestressing tendon (see Fig. 4; Kim et al. 2008). Unloading and reloading processes are accounted for through straight branches with an initial modulus.

The transverse reinforcements confine the compressed concrete in the core region and inhibit the buckling of the longitudinal reinforcing bars. In addition, the reinforcements improve the ductility capacity of the unconfined concrete. This study adopted the model proposed by Mander et al. (1988) for normal strength concrete of below $30 \mathrm{MPa}$ and adopted the model proposed by Sun and Sakino (2000) for high strength concrete of above $40 \mathrm{MPa}$. An analytical model was proposed for confined intermediate strength concrete from $30 \mathrm{MPa}$ to $40 \mathrm{MPa}$. The model incorporates all relevant parameters of confinement with a smooth transition from $30 \mathrm{MPa}$ to $40 \mathrm{MPa}$. The models consider the yield strength, the distribution type and the amount of the longitudinal and transverse reinforcing bars to compute the effective lateral confining stress and the ultimate compressive strength and strain of the confined concrete (Kim et al. 2008).

Details of the nonlinear material models used have been provided by the authors in previous research (Kim et al. 2003; Kim et al. 2007; Kim et al. 2008; Kim et al. 2009; Kim et al. 2010).

\section{Hollow Reinforced Concrete Bridge Columns}

\subsection{Description of Test Specimens}

The author used the data for the hollow reinforced concrete bridge columns under constant and variable axial load as proposed by Kawashima et al. (2002) to verify the applicability of the proposed method.

All columns had the same section dimensions of $400 \mathrm{~mm}$ square cross section with $100 \mathrm{~mm}$ thick walls (Fig. 5). Two rectangular hollow reinforced concrete columns were constructed and tested under axial compression and cyclic flexure. Figure 5 also shows the principal dimensions and loading arrangements of the column units. The TP-35, and TP-37 specimens shown had a height of $1350 \mathrm{~mm}$ $(l / d=3.86)$ and a spacing of $100 \mathrm{~mm}$ as web reinforcement. The longitudinal reinforcement consisted of twenty-four $13 \mathrm{~mm}$ diameter deformed bars (SD295). The transverse hoop steel was $6 \mathrm{~mm}$ diameter deformed bars (SD295).

The material properties of the specimens are listed in Table 1, and specimen names in the tables are those used by Kawashima et al. (2002).

The loading program included a combination of a constant, variable axial load and cyclic lateral displacement. Figures 6 and 7 show the cyclic load history, which was based on the lateral displacement pattern of increasing yield 

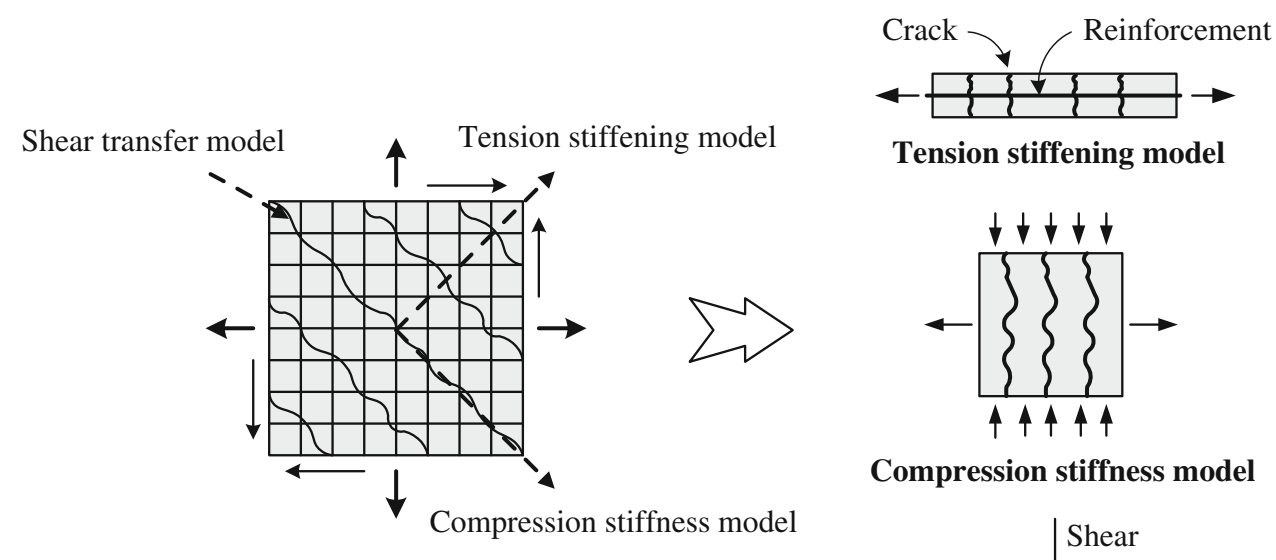

Tension stiffening model

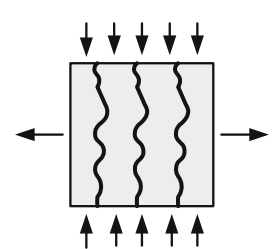

Compression stiffness model

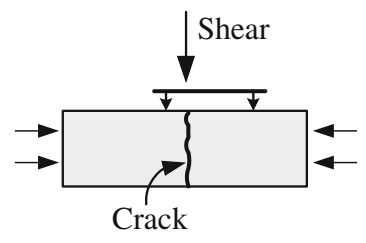

Shear transfer model

Fig. 2 Construction of cracked concrete model.

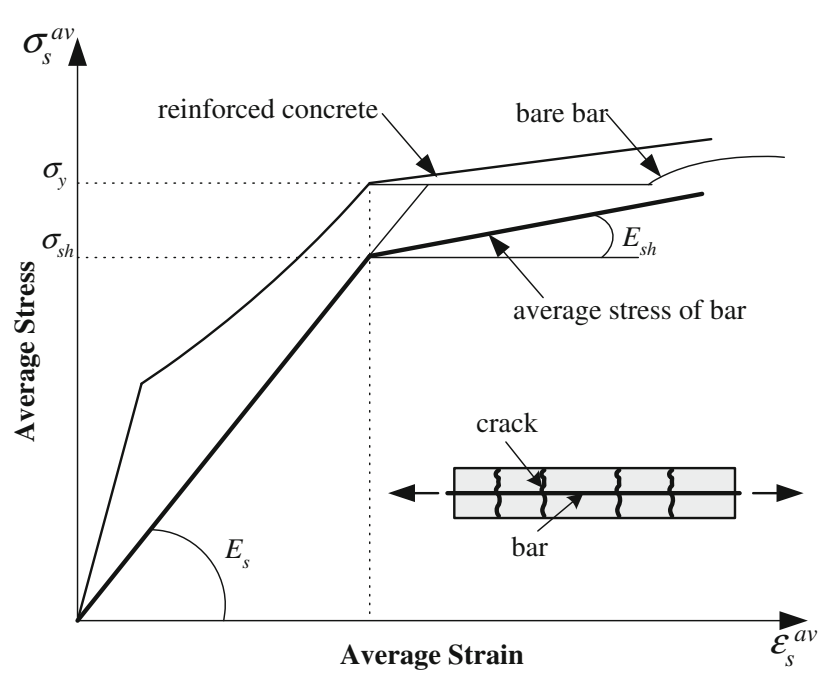

Fig. 3 Model for reinforcing bars in concrete.

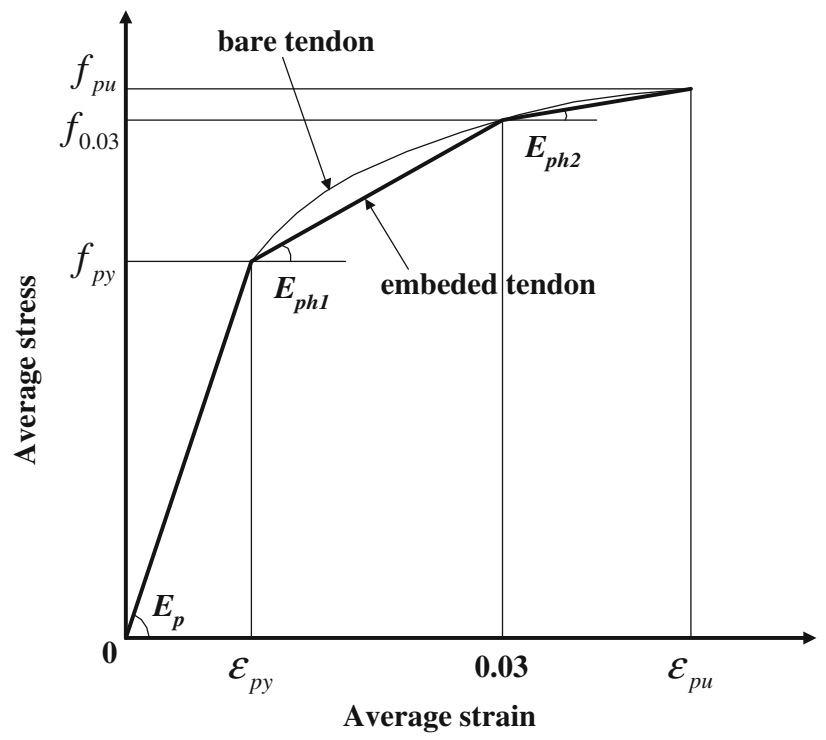

Fig. 4 Model for prestressing tendons.
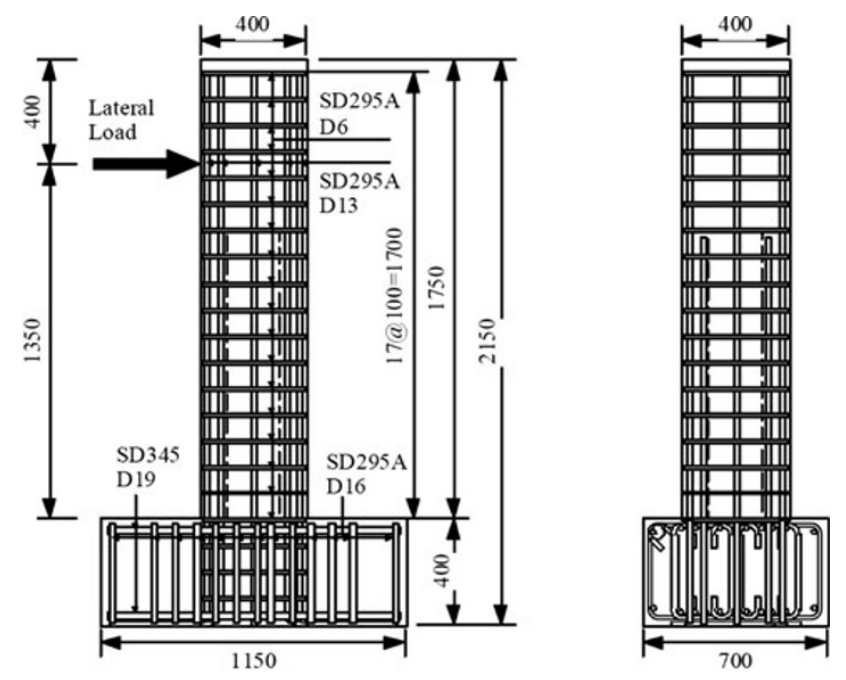

(a) Details of the specimen

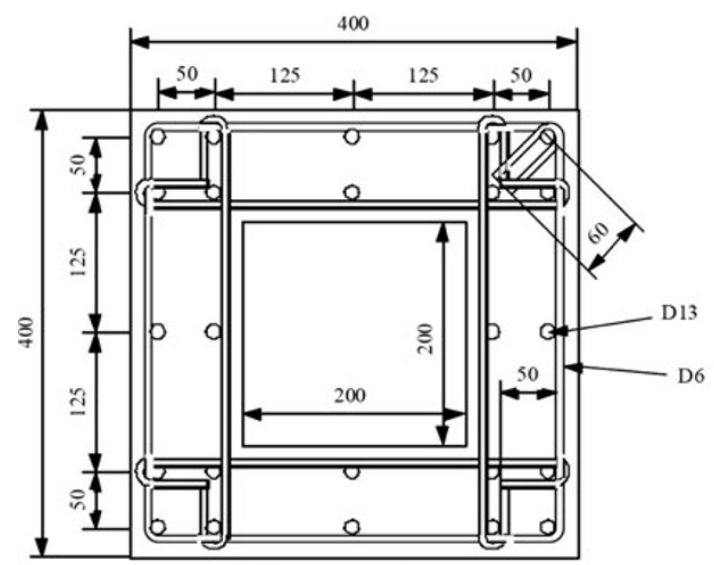

(b) Cross section

Fig. 5 Test specimens TP-35 and TP-37 (unit: mm) (Kawashima et al. 2002).

displacement. Subsequent cycles during the test were conducted in displacement control. Generally, it is well known that deformation performance around the ultimate state is 
Table 1 Properties of test specimens (Kawashima et al. 2002).

\begin{tabular}{|c|c|c|}
\hline Specimen & TP-35 & TP-37 \\
\hline Section & \multicolumn{2}{|c|}{ Square (hollow) } \\
\hline Section size $(\mathrm{mm})$ & \multicolumn{2}{|c|}{$400 \times 400(200 \times 200)$} \\
\hline Effective height (mm) & \multicolumn{2}{|c|}{1350} \\
\hline Effective depth (mm) & \multicolumn{2}{|c|}{350} \\
\hline Aspect ratio & \multicolumn{2}{|c|}{3.86} \\
\hline Longitudinal reinforcement ratio & \multicolumn{2}{|c|}{2.53} \\
\hline Volumetric ratio of tie reinforcement & \multicolumn{2}{|c|}{1.13} \\
\hline Cylinder strength of concrete (MPa) & \multicolumn{2}{|c|}{24.0} \\
\hline Longitudinal reinforcement & \multicolumn{2}{|c|}{ SD295A D13 (yield strength $=374 \mathrm{MPa}$ ) } \\
\hline Tie reinforcement & \multicolumn{2}{|c|}{ SD295A D6 (yield strength $=363 \mathrm{MPa}$ ) } \\
\hline Axial force $(\mathrm{kN})$ & 230 (constant) (2.0 MPa at the bottom) & $\begin{array}{c}-10 \text { to } 410 \text { (varying) (0-3.5 MPa at the } \\
\text { bottom) }\end{array}$ \\
\hline
\end{tabular}

deteriorated when the axial load is applied. Since the concrete area designed to bear the axial load is small in the hollow section, the bridge column loses the restoring force rapidly once the concrete begins to spall. From this result, it is found that the level of axial load is an important design parameter for hollow bridge columns.

\subsection{Description of Analytical Model}

Figure 8 shows the finite element discretization and the boundary conditions for two-dimensional plane stress nonlinear analyses of the hollow reinforced concrete bridge columns. The interface elements between the footing and the column enhanced the effects of the bond-slip of steel bars and the local compression (Kim et al. 2003).

The figures also show a method for transforming a hollow section into rectangular strips when using plane stress elements. For rectangular sections, equivalent strips are calculated. After the internal forces are calculated, the equilibrium is checked.

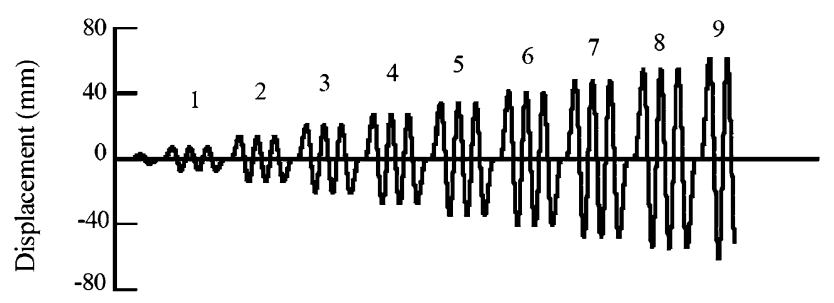

(i) Lateral Displacement

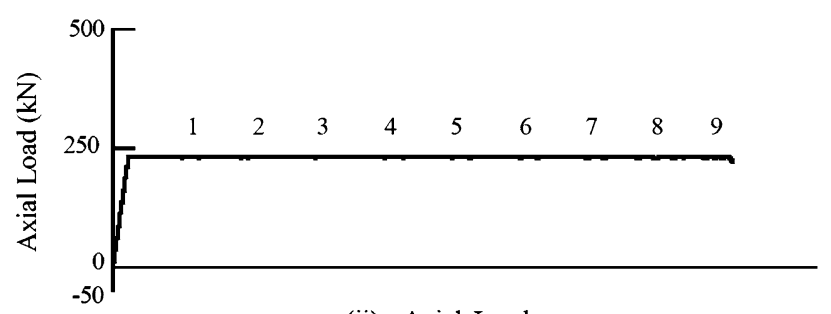

(ii) Axial Load

Fig. 6 Loading condition for specimen TP-35 (Kawashima et al. 2002).

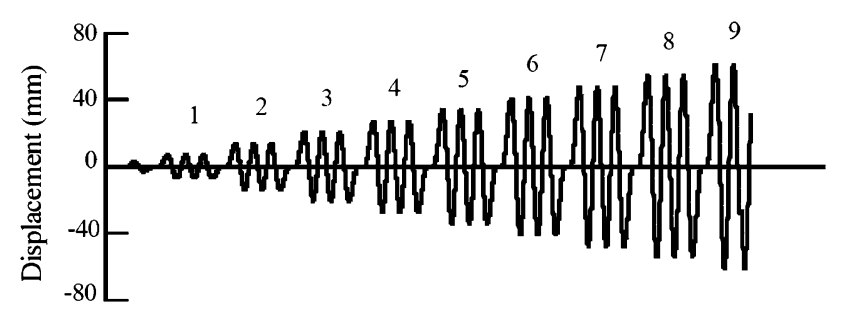

(i) Lateral Displacement

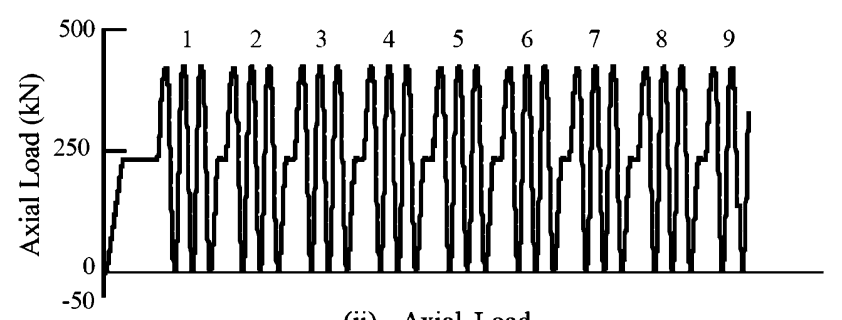

(ii) Axial Load

Fig. 7 Loading condition for specimen TP-37 (Kawashima et al. 2002).

Loading cycles with displacement control were applied as this allows analysis beyond the ultimate load where the load at the maximum strain was recognized from the load displacement curve.

\subsection{Comparison with Experimental Results}

Figures 9 and 10 show the hysteresis loops for horizontal load versus horizontal displacement at the loading point. The analytical results show reasonable agreement with the experimental results.

Results from all two test units show good correlation between the flexural plus the shear displacements and the total top displacement. For each of the test hollow reinforced concrete bridge columns, the predicted and the measured maximum loads were in good agreement. The analysis not only correctly predicted the stiffness, load, and deformation at the peak, but also captured the post-peak softening well. The predictions of the failure modes of all the hollow 


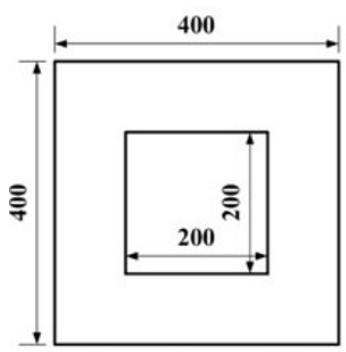

Hollow Section
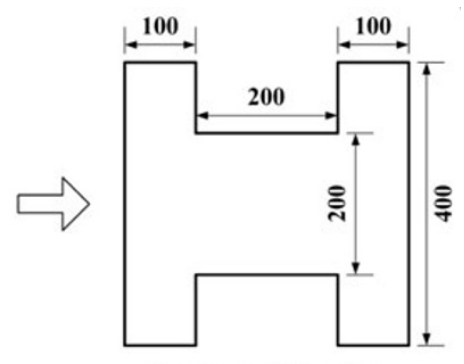

Equivalent Section (a) Transformation of a hollow column to an idealized equivalent rectangular column

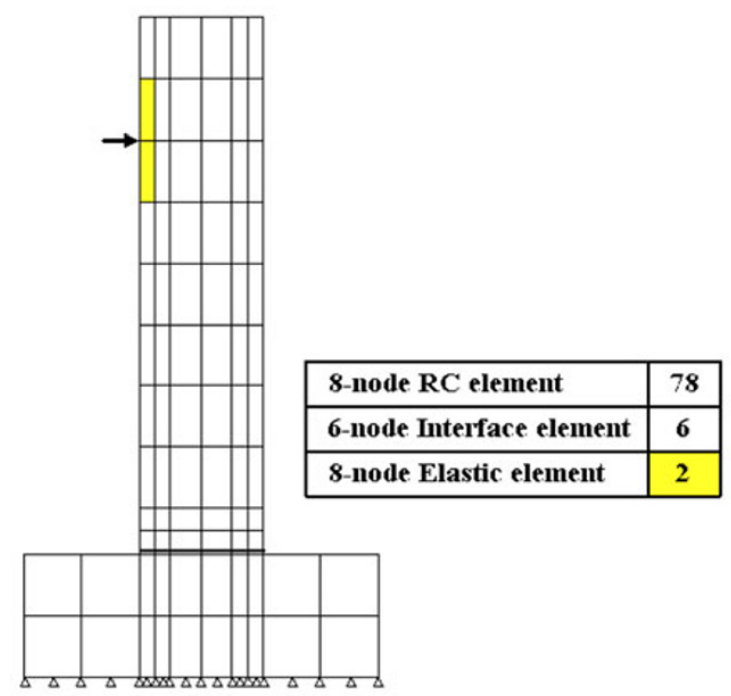

(b) Finite element mesh for analysis

Fig. 8 Finite element mesh for specimens.

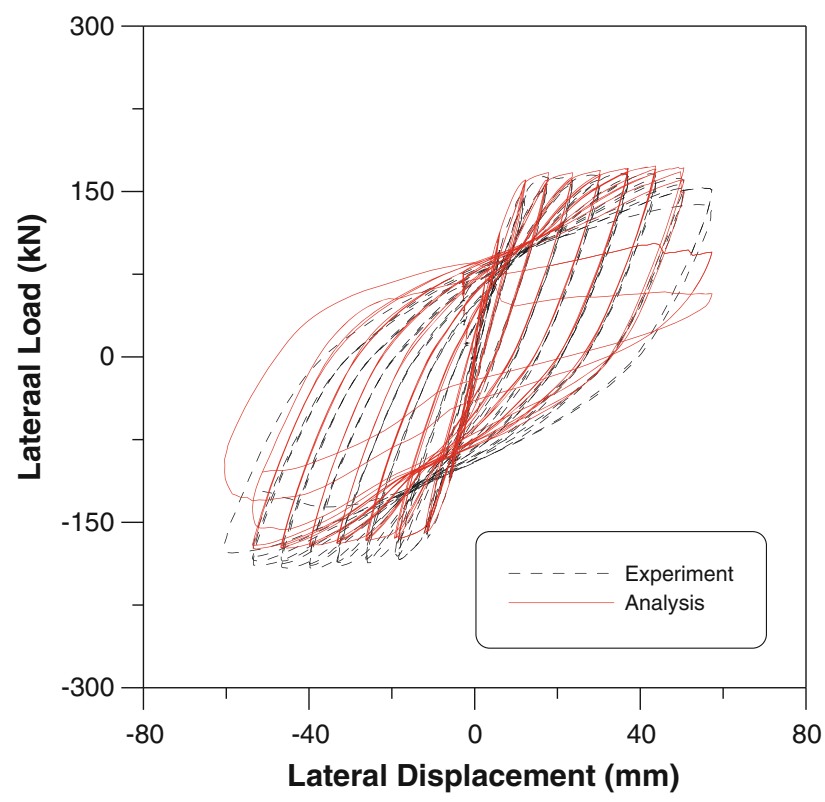

Fig. 9 Load-displacement curve for specimen TP-35.

reinforced concrete bridge column specimens also agree with the experimental results.

The hysteretic energy dissipation predictions are presented in Figs. 11 and 12 as red solid lines superimposed on the measured hysteretic behavior of the test units, displayed in black dashed lines. Excellent agreement was found between

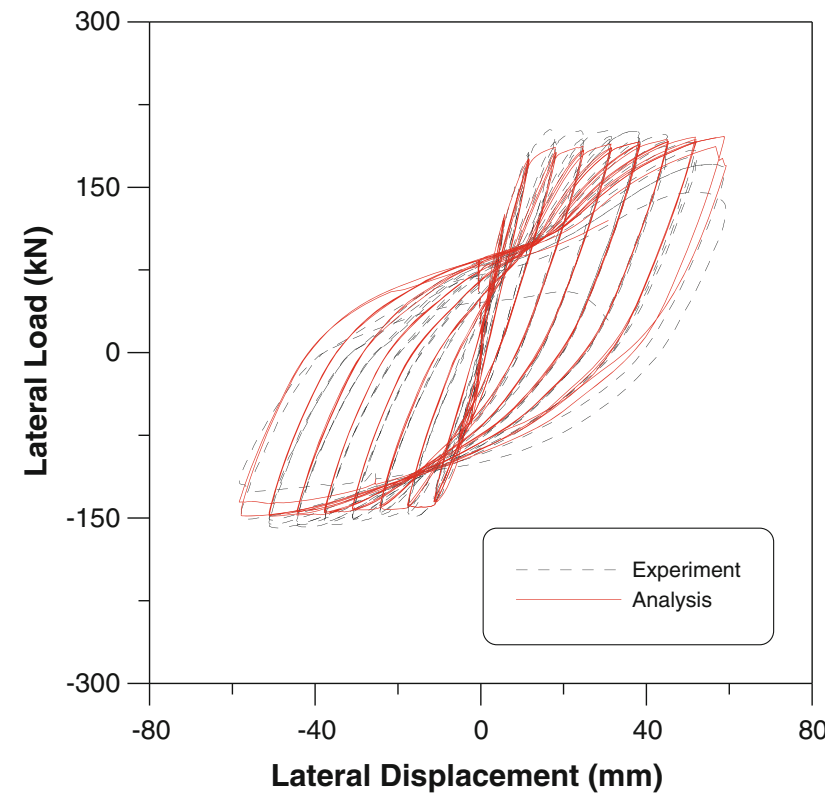

Fig. 10 Load-displacement curve for specimen TP-37.

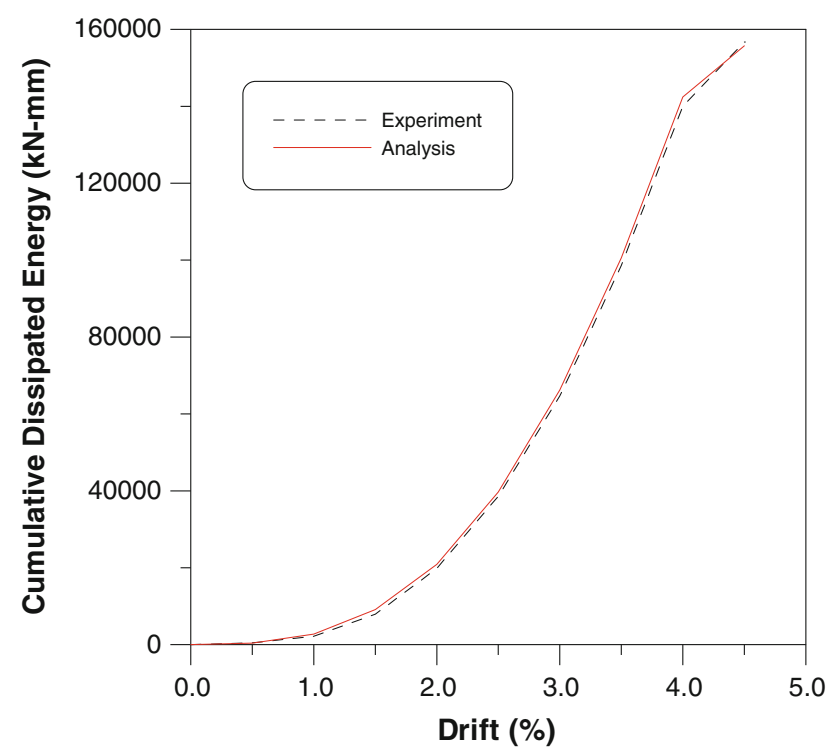

Fig. 11 Hysteretic energy dissipation for specimen TP-35.

the measured values and the predicted response. It was found that the hysteretic energy dissipation increased as the column drift increased.

Figures 13 and 14 show the failure pattern of specimens TP-35 and TP-37, respectively. Damage was concentrated only at the column-footing joint. The calculated failure sequence was in good agreement with the tested failure sequence (Kim et al. 2007). The final failure was due to the crushing of concrete, followed by the yielding of the longitudinal bars.

The characteristics of the response of the hollow reinforced concrete columns are clearly shown in the crack pattern. That is, the flexural cracks in the flange part drastically changed into diagonal cracks when they progressed into the web part (see Figs. 13 and 14). These diagonal cracks intersected under the cyclic loading, and the cracks in the vertical direction generated at the center of the sections. 


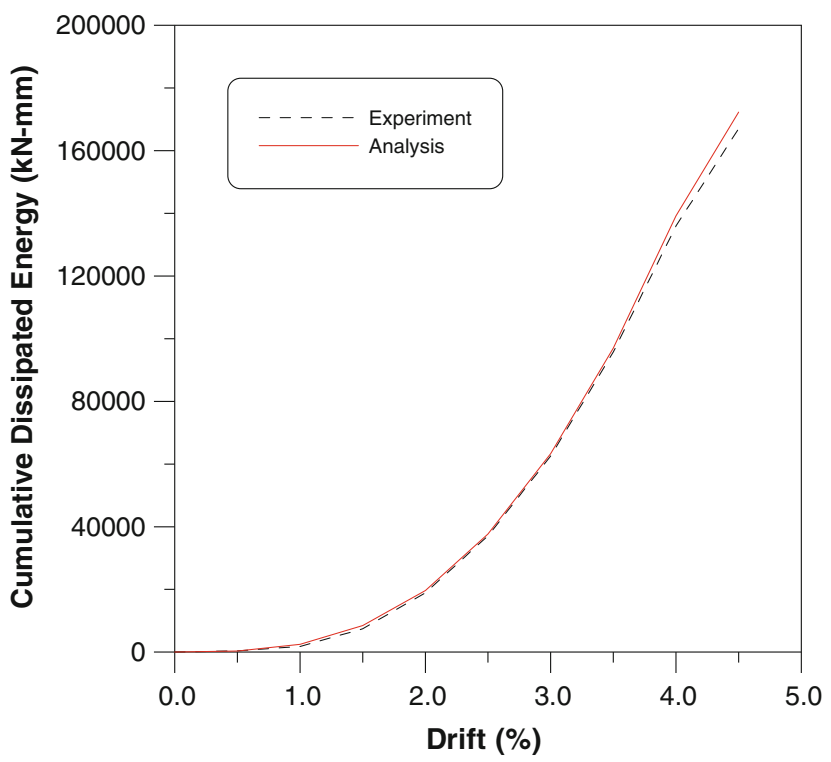

Fig. 12 Hysteretic energy dissipation for specimen TP-37.
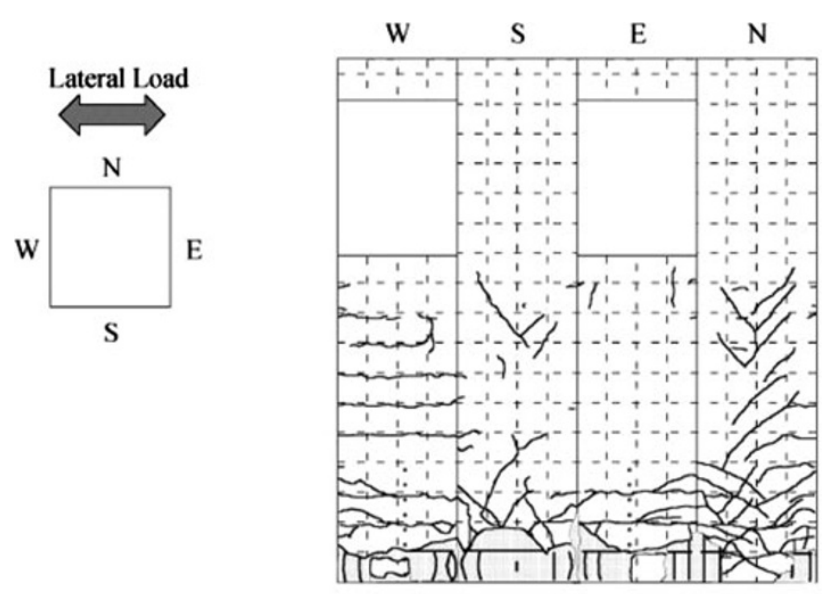

(a) Experiment
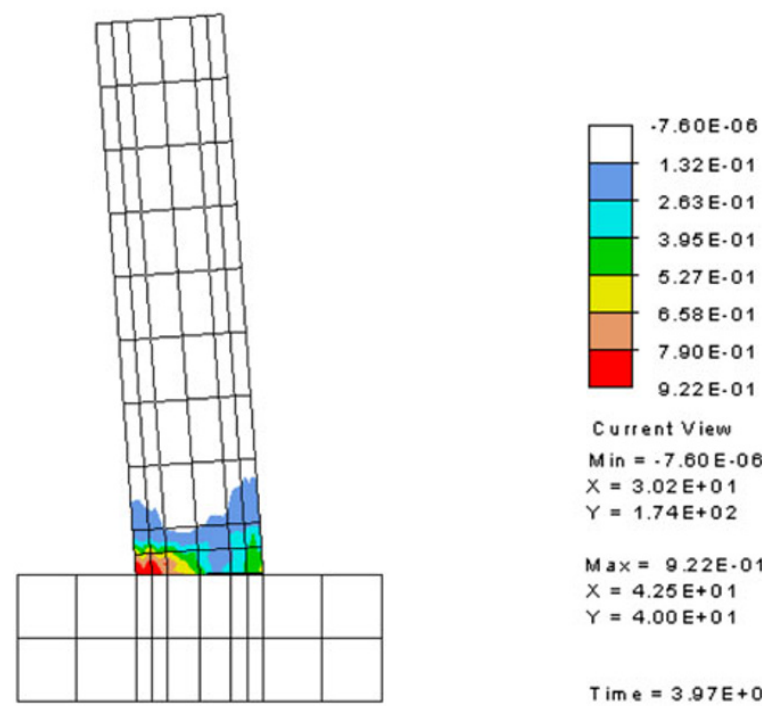

Current view

$M$ in $=.7 .60 \mathrm{E} \cdot 06$

$X=3.02 E+01$

$Y=1.74 E+02$

$\mathrm{Max}=9.22 \mathrm{E} \cdot 01$

$X=4.25 E+01$

$Y=4.00 E+01$

\section{(b) Analysis}

Fig. 13 Failure pattern for specimen TP-35.

This phenomenon was observed even in the case of specimens of flexural failure type. These experimental and analytical results indicate that the influence of shear cannot be
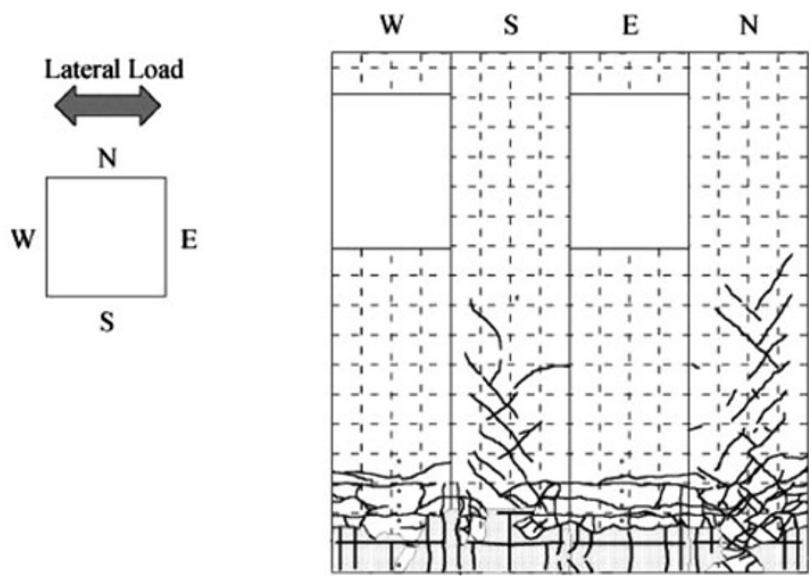

(a) Experiment

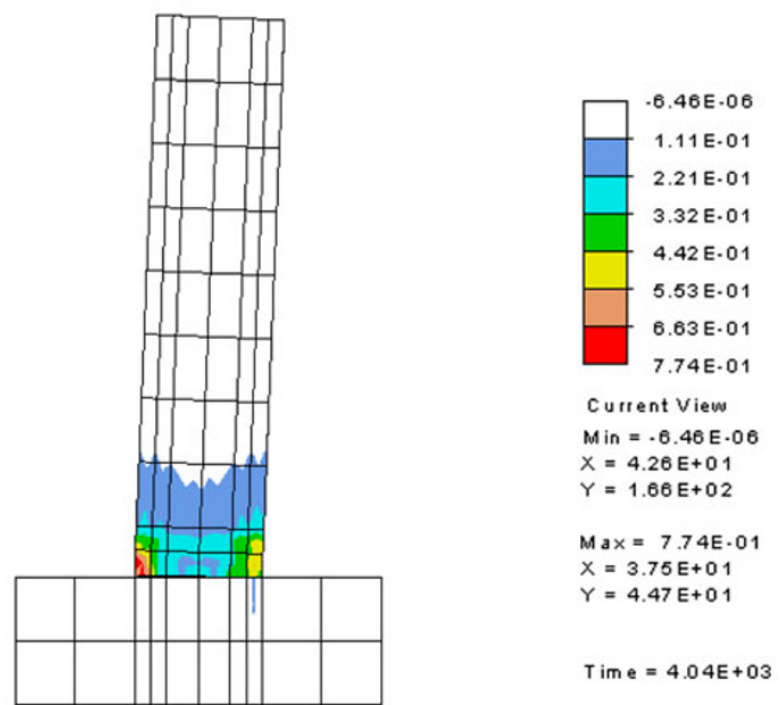

(b) Analysis

Fig. 14 Failure pattern for specimen TP-37.

neglected in hollow columns and it is necessary to examine sufficiently about the shear behavior under cyclic loadings.

As the overall tendency, the restoring force is rapidly decreased after the maximum state. The main reasons for this are that the spalling of concrete occurred not only outside but also inside the void and the buckling of reinforcements. Even in the case of flexural failure, in the web part, shear cracks appeared under small loads. Also, the flexural cracks in the flange part changed into diagonal cracks when they progressed into the web part. Furthermore, because of the spalling of concrete in the hollow side, the restoring capability after the maximum state deteriorated rapidly. Therefore, it is necessary to confine concrete by the appropriate transverse arrangement.

In specimen TP-37, the compression failure of concrete in the plastic hinge was always larger at the E surface than at the $\mathrm{W}$ surface, since the flexural compression and the compression due to the vertical load were combined, resulting in larger compression at the E surface than at the $\mathrm{W}$ surface (see Fig. 14). The variation of the axial load resulted in different responses in the push and pull directions. Apparently, the differences in direction and magnitude of the axial load caused significantly different damage patterns in 
the bridge columns. As observed during the test, there was a slight difference in the length of the crushed concrete at opposite sides of the hollow reinforced concrete bridge columns. The experimental and analytical results showed that the axial force level and pattern play a significant role in the behavior of the hollow reinforced concrete bridge columns. In the design of hollow reinforced concrete bridge columns it would be impossible for a design engineer to depict the sequence of loadings. Therefore, in order to mitigate the adverse effect of varying axial load, the extreme situations must be considered.

\section{Hollow Prestressed Concrete Bridge Columns}

\subsection{Description of Test Specimen}

One segmental hollow column specimen with precast concrete footings was designed for testing under lateral loading. The specimen is designed in accordance with the code provisions KRBDC (MCT 2005).

Figure 15 shows the developed precast segmental prestressed concrete bridge columns (Kim et al. 2010). Shear resistance connecting structures, which are continuous across the segment joints for enhanced shear transfer, were introduced in the prestressing tendon ducts.

The mechanical properties of the specimen are listed in Table 2 and the geometric details are shown in Fig. 16. The column specimen was tested under a $0.075 f_{c}^{\prime} A_{g}(1200 \mathrm{kN})$ constant compressive axial load to simulate the gravity load from bridge superstructures.

The specimen consisted of precast segments and foundation blocks. The foundation was $2600 \mathrm{~mm}$ by $1200 \mathrm{~mm}$ by $1200 \mathrm{~mm}$ (width by length by height). The precast segments were connected with a shear resistance connecting structure, and had no continuous bonded reinforcing across the segmental joints. Each segmental column specimen had eighteen prestressing strands. The confinement steel was designed to
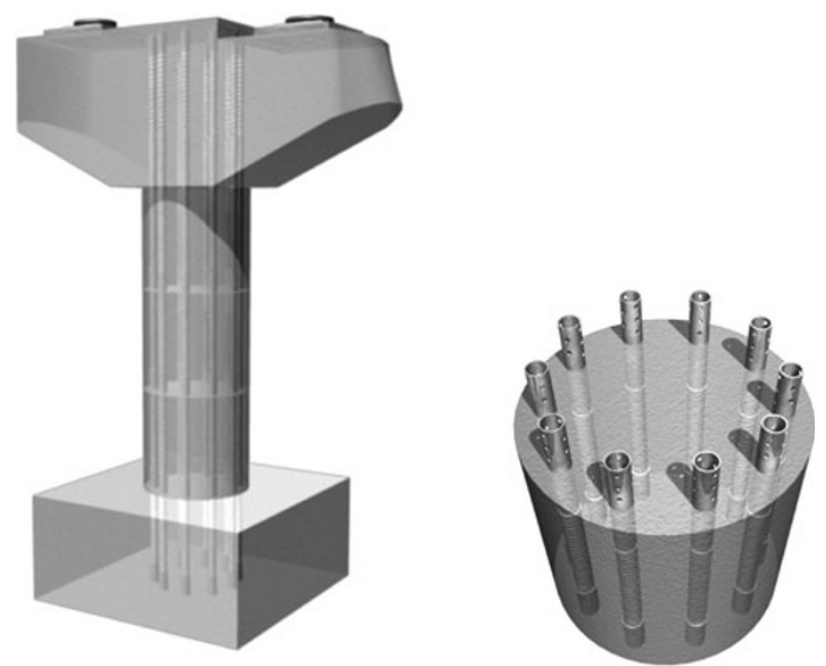

Fig. 15 Developed precast segmental prestressed concrete bridge columns with a shear resistant connecting structure (Kim et al. 2010). ensure that the core concrete exhibited a sufficient ductility capacity in compression. It is considered appropriate to use the current code provisions KRBDC (MCT 2005) on the concrete confinement for the potential plastic hinge regions in the design of precast segmental columns for use in moderate seismic regions.

The precast segments of the specimen were fabricated. To maximize construction speed and substructure durability, a system of match-cast segments with epoxy joints was developed. After the column was assembled, post-tensioning strands were tensioned to a predetermined stress level to satisfy both service and ultimate limit state requirements for the bridge column (Kim et al. 2010).

A schematic representation of the test set-up for the specimen is shown in Fig. 17. For each test, the column footing was connected to the laboratory strong floor by high strength post-tensioning bars. The cyclic lateral point load was applied at the column top by a servo-controlled $2600 \mathrm{kN}$ capacity hydraulic actuator with a $\pm 375 \mathrm{~mm}$ stroke reaching off the laboratory strong wall. Horizontal load levels in the actuator were monitored during the test through a load cell and the horizontal displacement at the actuator level was measured using a string displacement transducer and an independent reference column. The axial load assembly consisted of a spreader beam, high strength rods, manually controlled loading jacks, and load cells. The load was applied to the high strength rods on either side of the specimen and the load was transferred to the bridge column through the spreader beam.

For the specimen subject to cyclic loading, the loading was applied under displacement-control to drift levels of $0.25,0.5,1.0,1.5,2.0,2.5,3.0,3.5,4.0,4.5,5,6,7$ and $8 \%$. The drift was defined as the lateral displacement at the height of the loading point divided by the distance from the loading point to the top of the footing. Each cycle was repeated twice to allow for the observation of strength degradation under repeated loading with the same amplitude.

The lateral load-displacement responses for the specimen are shown in Fig. 18. Figure 18 also shows the design shear strength $(366 \mathrm{kN})$ of the columns and the damage pattern of the specimens at failure. The design shear strengths obtained from the design code KRBDC (MCT 2005) are conservative for the column specimen. The self-centering characteristic of the precast system is evidenced by the pinched hysteresis loops near the origin. The segmental hollow column specimen also exhibited ductile behavior under cyclic loading. Ultimate ductility capacity can be determined as 5.8, with a safe design limit of 5.0, providing a $20 \%$ reserve of displacement capacity.

\subsection{Description of Analytical Model}

A two-dimensional finite element model for the hollow prestressed concrete bridge columns is developed in this study. The modeling techniques of the segmental hollow bridge columns are described in the following sections.

Figure 19 shows the finite element discretization and the boundary conditions for two-dimensional plane stress nonlinear analyses of the hollow column specimens. The joints 
Table 2 Properties of test specimen.

\begin{tabular}{|c|c|c|}
\hline Specimen & Prototype & Model \\
\hline Diameter of cross section (mm) & $2200(1000)$ & $800(360)$ \\
\hline Effective height (mm) & 7522 & 2800 \\
\hline \multicolumn{3}{|c|}{ Prestressing steel } \\
\hline Material & $\begin{array}{c}\Phi 15.2 \mathrm{~mm} \\
\text { Seven-wire strands }\end{array}$ & $\begin{array}{c}\Phi 15.2 \mathrm{~mm} \\
\text { Seven-wire strands }\end{array}$ \\
\hline Yielding strength (MPa) & 1860.0 & 1968.2 \\
\hline Prestressing force (MPa) & 842.3 & 842.3 \\
\hline \multicolumn{3}{|c|}{ Longitudinal reinforcement } \\
\hline Material & D16 & D10 \\
\hline Yielding strength (MPa) & 400.0 & 544.6 \\
\hline Reinforcement ratio (\%) & 0.2 (Minimum) & 0.2 (Minimum) \\
\hline \multicolumn{3}{|c|}{ Transverse reinforcement } \\
\hline Material & D22 & D13 \\
\hline Yielding strength (MPa) & 400.0 & 476.3 \\
\hline Volumetric ratio $(\%)$ & 1.2 & 1.2 \\
\hline \multicolumn{3}{|c|}{ Footing reinforcement } \\
\hline Material & D32 & D32 \\
\hline Yielding strength (MPa) & 400.0 & 463.6 \\
\hline \multicolumn{3}{|c|}{ Shear resistance connecting structure } \\
\hline Material & STK490 (139.8/165.2 mm) & STK490 $(60.5 / 76.3 \mathrm{~mm})$ \\
\hline Yielding strength (MPa) & 315 & 315 \\
\hline \multicolumn{3}{|c|}{ Strength of concrete $(\mathrm{MPa})$} \\
\hline Footing & 40.0 & 48.1 \\
\hline Precast footing segment & 40.0 & 48.1 \\
\hline Column & 40.0 & 48.1 \\
\hline
\end{tabular}

between the precast segments with a shear resistance connecting structure were modeled using modified six-noded joint elements. In the joint model, the inelastic behavior of the joint elements is governed by normal and tangential stiffness coefficients. These relate the normal and tangential stresses of the joint to the normal and tangential relative displacements between the joint faces. The interface elements between the precast concrete footing segment and the cast-in-place footings enhance the modeling of the effects of localized discontinuous deformation. The bonded posttensioning tendons were modeled with two-noded truss elements that were attached at their end nodes to the concrete element nodes at the anchorage locations.

Figure 19 also shows a method for transforming a circular section into rectangular strips when using plane stress elements. For rectangular sections, equivalent strips are calculated. After the internal forces are calculated, the equilibrium is checked.

The analysis was conducted in multiple steps to simulate the actual behavior of a segmental column. The column was initially loaded under a prestressing force from the tendons. An initial stress equal to the prestress in the tendons was applied to the truss elements. Subsequently, a gravity load was applied on the top segment of the column and it remained vertical throughout the simulation. Finally, the column was subjected to the applied lateral displacements at the top, while the corresponding lateral force determined by the base shear developed at the bottom of the footing.

Geometric nonlinearity was considered in order for prestressing effects to be carried over from the initial step to the following steps and to take into account the P-delta effect from the axial force.

\subsection{Comparison with Experimental Results}

A comparison between the simulated and experimental load-displacement values for the specimen is shown in Fig. 20. The proposed analytical model successfully predicts the load-displacement relationship of hollow prestressed concrete bridge columns with flexure failure. 


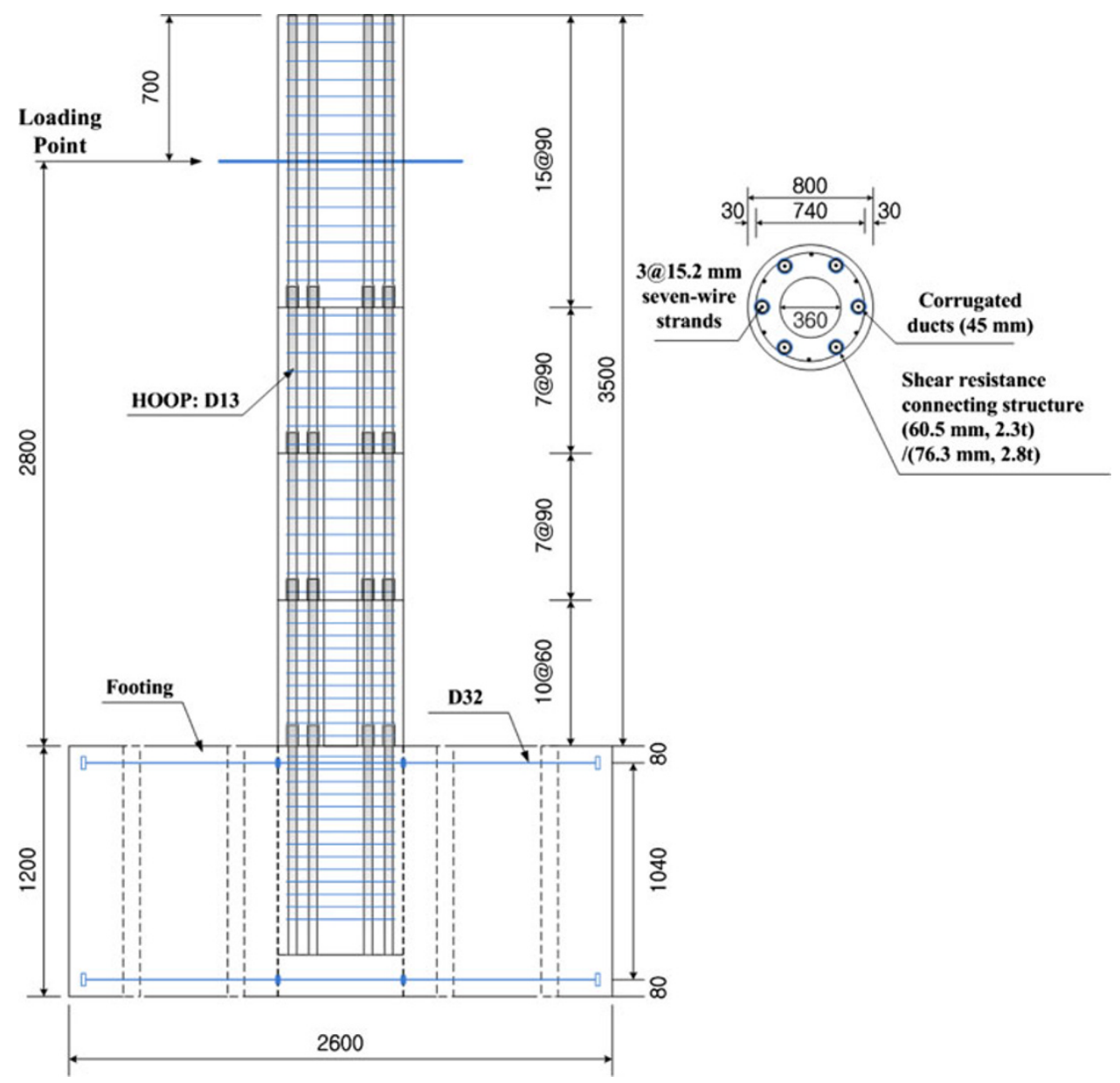

Fig. 16 Details of specimen.

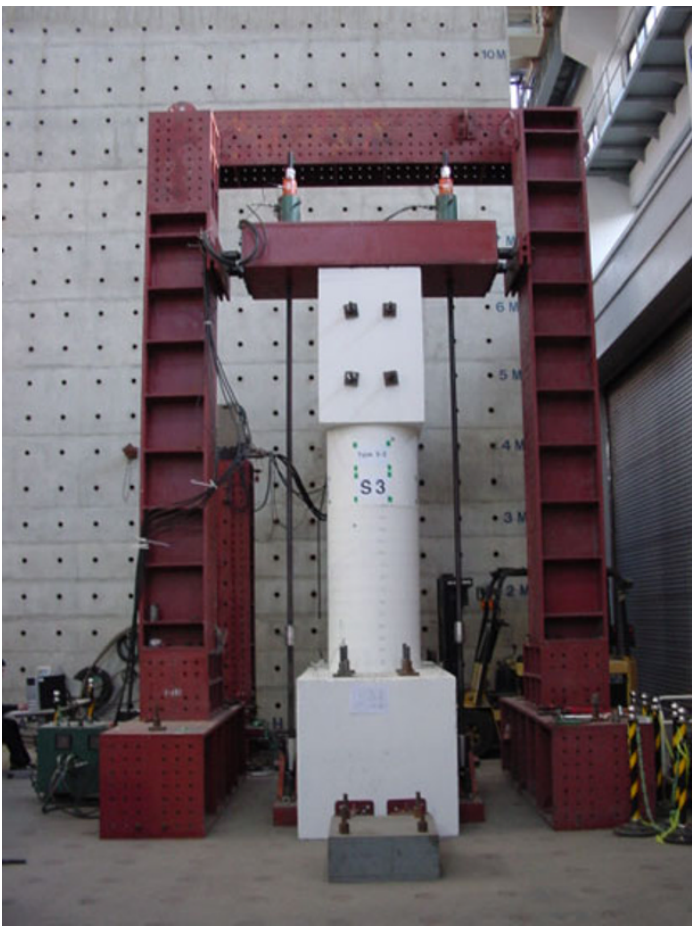

Fig. 17 Loading setup.

The analytical model presented herein correlated reasonably well with the experimentally observed behavior of the hollow columns. The predicted strength was higher than the

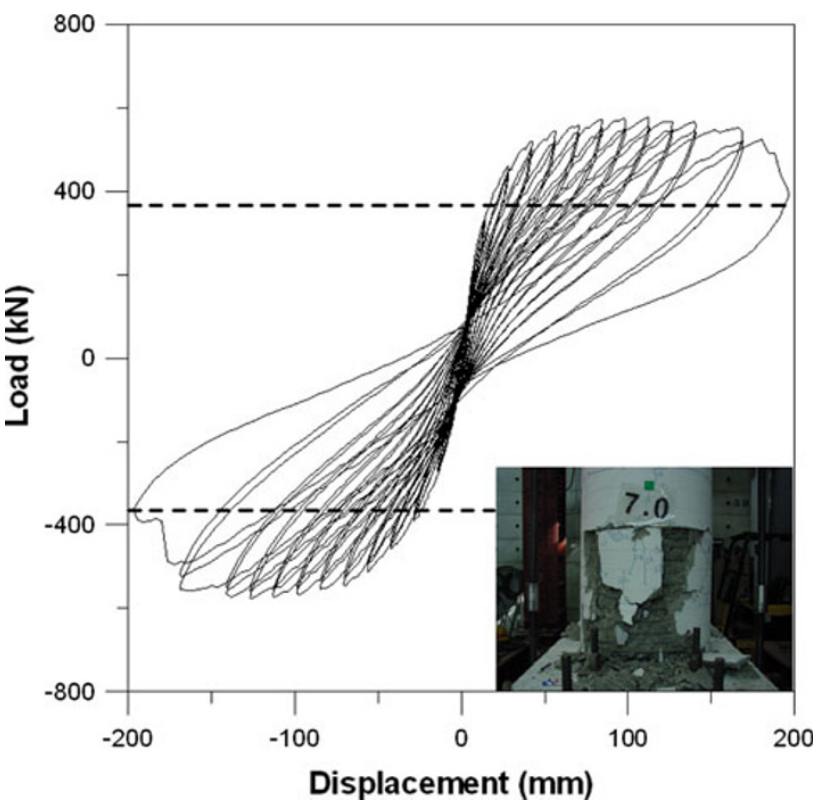

Fig. 18 Load-displacement curve for specimen.

actual column strength. The difference between the analytical and experimental force-displacement response at moderate to high drift levels is less than $3 \%$. In light of this, and of the uncertainty in the initial prestress force and the fact that the column had been tested previously, it can be said that the analytical prediction concurs well with the 


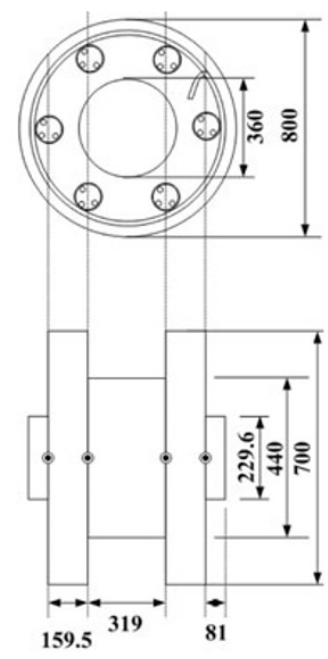

(a) Transformation of a hollow column to an idealized equivalent rectangular column

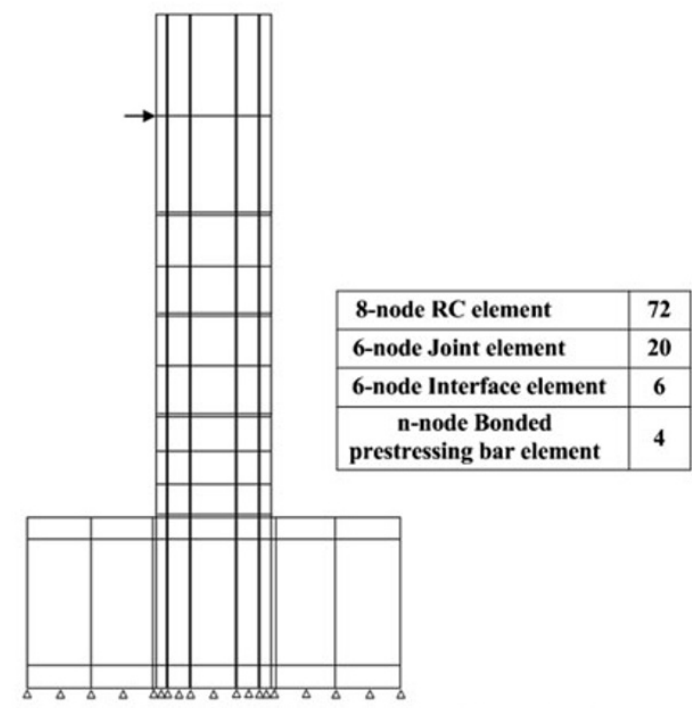

(b) Finite element mesh for analysis

Fig. 19 Finite element mesh for specimen.

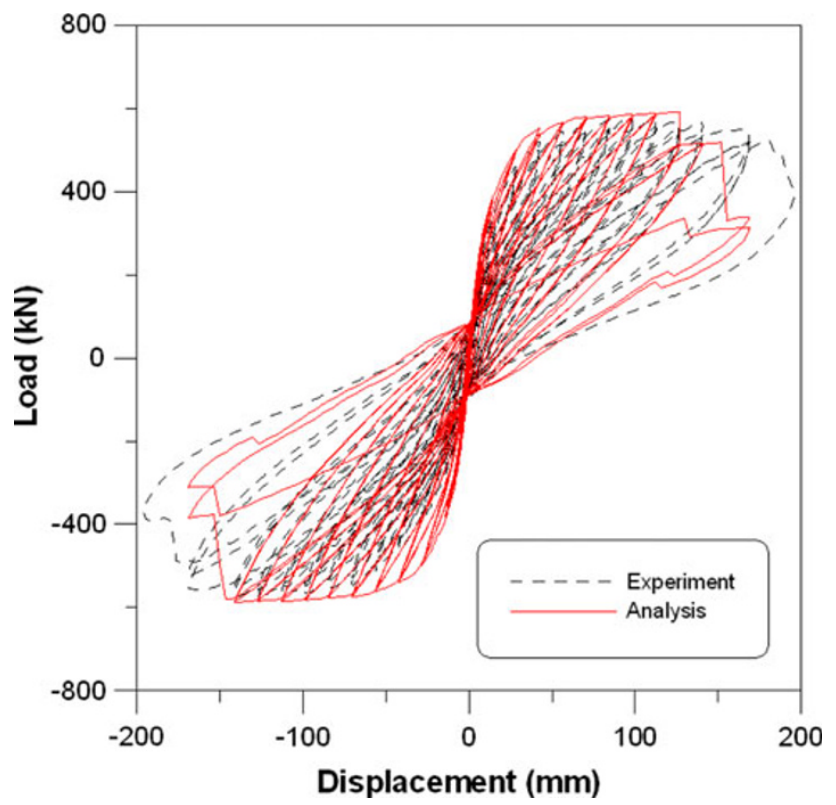

Fig. 20 Comparison of results from the experimental results.

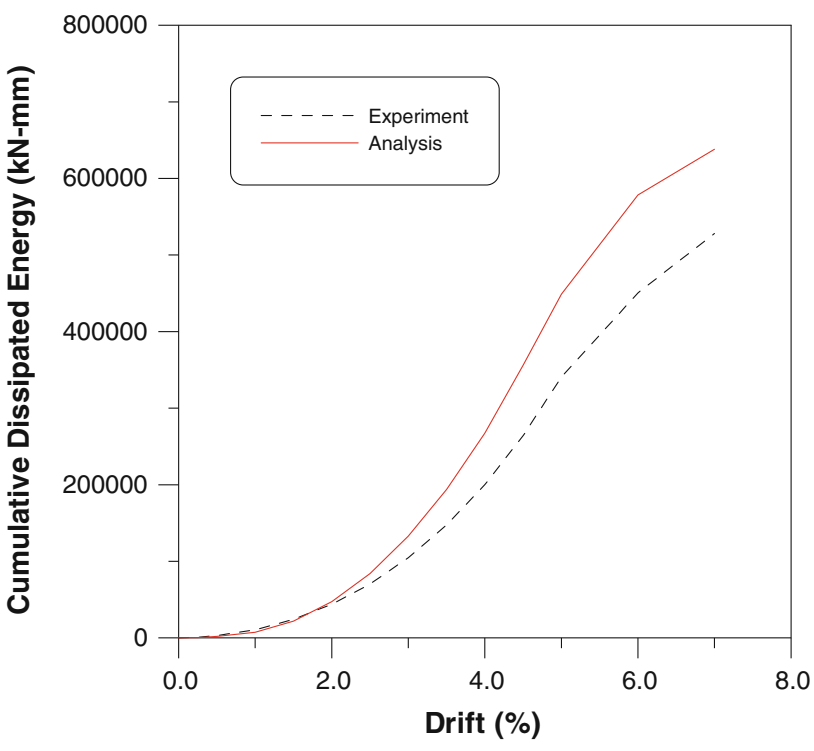

Fig. 21 Hysteretic energy dissipation for specimen.

experimental behavior. In terms of cyclic behavior, the simulation successfully captures the wide hysteretic loops. The stiffness in the simulation is considerably greater than that of the experiment.

The hysteretic energy dissipation of the specimen was evaluated based on the cumulative dissipation energy as shown in Fig. 21. It was found that the hysteretic energy dissipation increased as the column drift increased.

The importance of identifying and evaluating the adequacy of simulation methods is an important and necessary step in applying performance-based assessment techniques for assessing new, enhanced performance systems under consideration. Such an assessment can help to speed the implementation of such systems in current applications.

\section{Conclusions}

This paper has attempted to establish a framework for assessment of the seismic performance of hollow reinforced concrete and prestressed concrete bridge columns. An experimental and analytical study was conducted to quantify performance measures and to examine one aspect of detailing for hollow bridge columns. A comparison with test data confirms that good predictions were obtained in regards to load capacities, failure modes, and load-deformation responses of hollow reinforced concrete and prestressed concrete bridge columns. The RCAHEST can be used for examining the seismic performance of structures that have been previously designed.

From the results of the experimental and analytical studies, the following conclusions were reached.

(a) The material models used for modeling concrete, reinforcing bars and tendon in this study are found to give promising results for the seismic performance assessment of the hollow reinforced concrete and prestressed concrete bridge columns. 
(b) Nonlinear finite element analysis may be used to investigate the design details and the load-deflection response of hollow reinforced concrete and prestressed concrete bridge columns. Also, failure modes and ductility may be checked for seismic resistant design.

(c) The experimental and analytical results showed that the axial force level and pattern play a significant role in the behavior of the hollow bridge columns. In the design of hollow bridge columns it would be impossible for a design engineer to depict the sequence of loadings. Therefore, to mitigate the adverse effect of a varying axial load, the extreme situations must be considered.

(d) The reversed cyclic loading tests are said to simulate a loading history due to earthquakes. However, the behavior of hollow reinforced concrete and prestressed concrete bridge columns is complicated because of the interaction between flexure and shear, and the reversed cyclic loads. Therefore, to investigate the real seismic behavior of hollow reinforced concrete and prestressed concrete bridge columns, it is necessary to carry out a hybrid earthquake loading test.

(e) More effort should be directed to include certain procedures in the current design codes so that engineers can work toward an acceptable method for evaluating the available strength in existing hollow reinforced concrete and prestressed concrete bridge columns.

(f) Future work by the authors will include the formulation of a refined hollow section confinement model for various section geometries, transverse reinforcement configurations, and axial loads. Also, parametric studies will be conducted in order to investigate the effects of confinement on hollow bridge columns.

\section{Acknowledgments}

The author is especially grateful to Prof. Kazuhiko Kawashima for providing the test results in this study.

\section{Open Access}

This article is distributed under the terms of the CreativeCommons Attribution License which permits any use, distribution, and reproduction in any medium, provided theoriginal author(s) and the source are credited.

\section{References}

Hines, E. M., Seible, F., \& Priestley, M. J. N. (2002). Seismic performance of hollow rectangular reinforced concrete piers with highly-confined boundary elements Phase I:
Flexural tests Phase II: Shear tests. Report No. SSRP-99/ 15, University of California, San Diego, La Jolla, CA.

Hoshikuma, J., \& Priestley, M. J. N. (2000). Flexural behavior of circular hollow columns with a single layer of reinforcement under seismic loading. Report No. SSRP-2000/ 13, University of California, San Diego, La Jolla, CA.

Kato, B. (1979). Mechanical properties of steel under load cycles idealizing seismic action. CEB Bulletin D'Information, 131, 7-27.

Kawashima, K., Une, H., \& Sakai, J. (2002). Seismic performance of hollow reinforced concrete arch ribs subjected to cyclic lateral force under varying axial load. Journal of Structural Engineering, JSCE, 48A, 747-757.

Kim, T.-H., Hong, H.-K., Chung, Y.-S., \& Shin, H. M. (2009). Seismic performance assessment of reinforced concrete bridge piers with lap splices using shaking table tests. Magazine of Concrete Research, 61(9), 705-719.

Kim, T.-H., Kim, Y.-J., Kang, H.-T., \& Shin, H. M. (2007). Performance assessment of reinforced concrete bridge columns using a damage index. Canadian Journal of Civil Engineering, 34(7), 843-855.

Kim, T.-H., Lee, K.-M., Yoon, C.-Y., \& Shin, H. M. (2003). Inelastic behavior and ductility capacity of reinforced concrete bridge piers under earthquake. I: Theory and formulation. Journal of Structural Engineering, ASCE, 129(9), 1199-1207.

Kim, T.-H., Park, J.-G., Kim, Y.-J., \& Shin, H. M. (2008). A computational platform for seismic performance assessment of reinforced concrete bridge piers with unbonded reinforcing or prestressing bars. Computers and Concrete, 5(2), 135-154.

Kim, T.-H., Park, S.-J., Kim, Y.-J., \& Shin, H. M. (2010). Performance assessment of precast segmental PSC bridge columns with precast concrete footings. Magazine of Concrete Research, 62(11), 773-787.

Maekawa, K., Pimanmas, A., \& Okamura, H. (2001). Nonlinear mechanics of reinforced concrete. London: SPON Press.

Mander, J. B., Priestley, M. J. N., \& Park, R. (1988). Theoretical stress-strain model for confined concrete. Journal of Structural Engineering, ASCE, 114(8), 1804-1826.

Ministry of Construction and Transportation. (2005). Korea roadway bridge design code. Korea: MCT.

Mo, Y. L., Wong, D. C., \& Maekawa, K. (2003). Seismic performance of hollow bridge columns. ACI Structural Journal, 100(3), 337-348.

Ranzo, G., \& Priestley, M. J. N. (2001). Seismic performance of circular hollow columns subjected to high shear. Report No. SSRP-2001/01, University of California, San Diego, La Jolla, CA.

Shima, H., Chou, L., \& Okamura, H. (1987). Micro and macro models for bond behavior in reinforced concrete. Journal of the Faculty of Engineering, University of Tokyo (B), 39(2), 133-194.

Sun, Y.-P., \& Sakino, K. (2000). A comprehensive stress-strain model for high strength concrete confined by circular 
transverse reinforcement. In The 6th ASCCS international conference on steel-concrete composite structures, University of Southern California, pp. 1067-1074.

Taylor, R. L. (2000). FEAP - a finite element analysis program, version 7.2 users manual (Volumes 1 \& 2). Berkeley, CA: University of California at Berkeley.

Yeh, Y.-K., Mo, Y. L., \& Yang, C. Y. (2002). Seismic performance of rectangular hollow bridge columns. Journal of Structural Engineering, ASCE, 128(1), 60-68.
Zahn, F. A., Park, R., \& Priestley, M. J. N. (1990). Flexural strength and ductility of circular hollow reinforced concrete columns without confinement on inside face. ACI Structural Journal, 87(2), 156-166. 